\title{
Pendampingan Keluarga dalam Pencegahan dan Perawatan Dispepsia
}

\author{
Nur Wahyuni Munir ${ }^{1 *}$, Wa Ode Sri Asnaniar ${ }^{2}$, Suhermi $^{3}$ \\ 1,2,3 Program Studi IImu Keperawatan, Universitas Muslim Indonesia
}

\section{*Nur Wahyuni Munir \\ Email: nurwahyuni.munir@umi.ac.id \\ Alamat: Jl. Urip Sumoharjo Km. 5 \\ Kampus Universitas Muslim Indonesia \\ Makassar}

\author{
History Artikel \\ Received : 13-07-2021 \\ Accepted: $14-08-2021$ \\ Published: $31-08-2021$
}

\begin{abstract}
Abstrak
Dispepsia adalah gejala yang dirasakan pasien diantara pusar dan prosesus xyphoideus, diantaranya nyeri epigastrik, sensasi tekanan dan rasa penuh, mual, dan rasa kenyang subyektif awal. Penyebab kontribusinya termasuk gangguan motilitas, hipersensitivitas viseral, permeabilitas mukosa yang meningkat, dan gangguan otonom dan sistem saraf enterik. Belum ada pengobatan yang diarahkan secara kausal untuk dispepsia fungsional. Tujuan untuk meningkatkan pengetahuan pasien dispepsia dan keluarganya terkait cara pencegahan dan perawatan dispepsia. Oleh karena itu, dilakukan penyuluhan kesehatan untuk meningkatkan pengetahuan pasien dispepsia dan keluarganya tentang penyebab, proses terjadinya, tanda dan gejala, bahaya, cara perawatan dan pencegahan, cara minum obat, dan obat tradisional untuk dispepsia. Metode yang digunakan, yaitu ceramah, diskusi, dan demonstrasi. Media yang digunakan, yaitu leaflet, poster, soal pretest dan posttest. Hasil kegiatan pengabdian ini menunjukkan terjadi peningkatan pengetahuan kategori baik sebesar 50\% sebelum dan setelah dilakukan penyuluhan. Disarankan untuk pengabdian berikutnya di komunitas sehingga dapat mendemonstrasikan langsung cara pengolahan obat tradisional untuk dispepsia.
\end{abstract}

Kata Kunci: Dispepsia; Keluarga; Pencegahan; Pendampingan; Perawatan

\begin{abstract}
Dyspepsia is a symptom felt by the patient between the navel and the xyphoid process, including epigastric pain, sensation of pressure and fullness, nausea, and early subjective satiety. Contributing causes include impaired motility, visceral hypersensitivity, increased mucosal permeability, and disorders of the autonomic and enteric nervous systems. There is no causally directed treatment for functional dyspepsia. The purpose of this activity is to increase the knowledge of dyspepsia patients and their families regarding how to prevent and treat dyspepsia. Therefore, health education is carried out to increase knowledge of dyspepsia patients and their families about the causes, processes of occurrence, signs and symptoms, dangers, ways of treatment and prevention, how to take medicine, and traditional medicines for dyspepsia. The methods used are lectures, discussions, and demonstrations. The media used were leaflets, posters, pretest and posttest questions. The results of this service activity showed an increase in knowledge in both categories by $50 \%$ before and after counseling. It is recommended for the next service in the community so that they can demonstrate directly how to process traditional medicines for dyspepsia.
\end{abstract}

Keyword: Dyspepsia; Family; Prevention; Accompaniment; Care 


\section{Pendahuluan}

Dispepsia adalah gejala yang dirasakan pasien diantara pusar dan prosesus xyphoideus, diantaranya nyeri epigastrik, sensasi tekanan dan rasa penuh, mual, dan rasa kenyang subyektif awal. Etiologi kelainan ini heterogen dan multifaktorial. Penyebab kontribusinya termasuk gangguan motilitas, hipersensitivitas viseral, permeabilitas mukosa yang meningkat, dan gangguan otonom dan sistem saraf enterik. Belum ada pengobatan yang diarahkan secara kausal untuk dispepsia fungsional.

Perawatannya harus dimulai dengan pendidikan pasien yang intensif mengenai sifat jinak dari gangguan tersebut dan dengan pembentukan pakta terapeutik untuk pengasuhan jangka panjang. Mengingat tidak adanya pengobatan yang diarahkan secara kausal, obat untuk mengobati dispepsia fungsional harus diberikan tidak lebih dari 8-12 minggu. Penghambat pompa proton, obat fitoterapi, dan pemberantas Helicobacter pylori berbasis bukti intervensi. Untuk kasus yang sulit ditangani, antidepresan trisiklik dan psikoterapi adalah pilihan pengobatan yang lebih efektif (Madisch et al., 2018). Gejala yang disebutkan untuk dispepsia fungsional harus terjadi pada setidaknya tiga bulan terakhir dengan onset gejala enam bulan sebelum diagnosis ditentukan (Syam et al., 2017).

Prevalensi dispepsia dalam kesehatan unit perawatan mencapai $30 \%$ dari layanan yang ditawarkan oleh dokter umum dan $50 \%$ layanan oleh ahli gastroenterologi. Sebagian besar pasien Asia dengan dispepsia yang tidak diinvestigasi dan tanpa dispepsia tanda alarm mengalami dispepsia fungsional.

Hasil studi di negara-negara Asia (Cina, Hong Kong, Indonesia, Korea, Malaysia, Singapura, Taiwan, Thailand dan Vietnam) yang dimiliki oleh 43 hingga 79,5\% pasien dispepsia disfungsional (Miwa et al., 2012).

Dari hasil endoskopi yang dimilikinya telah dilakukan pada 550 pasien dispepsia di beberapa pusat di Indonesia antara bulan Januari 2003 dan April 2004, ada 44,7\% kasus dengan gangguan gastritis dan duodenitis minimal; 6,5 kasus dengan tukak lambung dan $8,2 \%$ normal kasus. $\mathrm{Di}$
Indonesia, data prevalensi Hp infeksi pada pasien dengan tukak lambung (tanpa riwayat penggunaan anti-inflamasi nonsteroid obat-obatan (NSAIDS)) bervariasi antara 90 dan $100 \%$ dan untuk pasien dengan dispepsia fungsional, prevalensinya $20-40 \%$ dengan berbagai diagnostik metode (pemeriksaan serologi, kultur dan histopatologi). Prevalensi infeksi $\mathrm{Hp}$ pada pasien dengan dispepsia yang menjalani endoskopi pemeriksaan di berbagai rumah sakit pendidikan di Indonesia antara 2003 dan 2004 adalah 10,2\%. Prevalensi yang relatif tinggi ditemukan di Makassar sebesar 55\% (2011) dan di Solo as sebanyak 51,8\% (2008). Prevalensi tinggi adalah juga ditemukan di Yogyakarta sebesar 30,6\% dan Surabaya dari $23,5 \%$ pada 2013; sedangkan prevalensi terendah ditemukan di Jakarta (8\%) (Hidayati et al., 2013; Parewangi, 2011).

RSUD Haji Makassar tepatnya pada Ruang Rinra 1 adalah ruang rawat inap interna dan bedah. Pada seminggu terakhir bulan April sekitar $80 \%$ pasien yang dirawat mengalami dyspepsia. Berdasarkan hasil wawancara, beberapa pasien dan keluarganya tidak mengetahui penyebab dan cara perawatan dispepsia. Oleh karena itu, kegiatan pengabdian yang akan dilakukan terkait cara pencegahan dan perawatan dyspepsia berbasis pendampingan keluarga.

\section{Metode}

Metode yang digunakan, yaitu ceramah, diskusi, dan demonstrasi. Kegiatan ini dilaksanakan selama satu hari pada hari Sabtu tanggal 25 Mei 2021. Kegiatan penyuluhan kesehatan dilakukan di Ruang Rawat Inap Rinra Sayang I RSUD Haji Makassar pukul 09.00 s/d 10.00 WITA. Sebelum dilakukan penyuluhan, setiap peserta diberikan pre-test dan di akhir sesi diadakan post-test. Media yang digunakan adalah poster dan leaflet. Tim Pelaksana berperan sebagai narasumber dan fasilitator saat kegiatan berlangsung. Peserta yang hadir pada kegiatan ini sebanyak 10 orang pasien dan atau keluarganya, 9 orang mahasiswa Profesi Ners Universitas Muslim Indonesia, 3 orang 
mahasiswa profesi ners dari instansi lain, kepala ruangan, dan tim dosen pengabdi.

\section{Hasil dan Pembahasan}

Kegiatan dibuka oleh Kepala Ruangan kemudian tim pengabdi memperkenalkan diri. Selanjutnya dilakukan pre-test tentang pencegahan dan perawatan dyspepsia kepada peserta penyuluhan. Kemudian ketua tim pengabdi melakukan penyuluhan kesehatan tentang pendampingan keluarga dalam pencegahan dan perawatan dispepsia dan diakhiri dengan diskusi tamnya jawab dengan pasien dan atau keluarga pasien yang ikut serta dalam kegiatan. Penyuluhan ini berisi tentang pengertian, penyebab, proses terjadinya, tanda dan gejala, bahaya, cara perawatan dan pencegahan, cara minum obat, dan obat tradisional untuk dispepsia. Materi yang diberikan sesuai dengan yang ada pada soal pre-test, sehingga setelah penyuluhan berakhir kemudian diberikan post-test dengan soal yang sama.

Tabel 1. Distribusi Pengetahuan Sebelum dan Setelah Penyuluhan

\begin{tabular}{lcccc}
\hline \multirow{2}{*}{ Pengetahuan } & \multicolumn{2}{c}{ Pre-Test } & \multicolumn{2}{c}{ Post-Test } \\
\cline { 2 - 5 } & $\mathbf{n}$ & $\%$ & $\mathbf{n}$ & $\%$ \\
\hline Baik & 4 & 40 & 9 & 90 \\
\hline Kurang & 6 & 60 & 1 & 1 \\
\hline \multicolumn{1}{c}{ Jumlah } & 10 & 100 & 10 & 100 \\
\hline
\end{tabular}

Tabel 1 menunjukkan terjadinya peningkatan pengetahuan masyarakat terkait pencegahan dan perawatan dispepsia. Sebelum diberikan penyuluhan, sebanyak $60 \%$ pasien dan atau keluarga pasien memiliki pengetahuan yang kurang dan setelah diberikan penyuluhan, sebanyak $90 \%$ pasien dan atau keluarga pasien telah memiliki pengetahuan yang baik. Hal ini menunjukkan bahwa terjadi peningkatan pengetahuan kategori baik sebesar $50 \%$ sebelum dan setelah dilakukan penyuluhan.

Salah satu pertanyaan pasien saat sesi tanya jawab di akhir penyuluhan terkait seringnya ulu hati terasa perih ketika terlambat makan. Narasumber kemudian menjelaskan tentang pentingnya menjaga pola makan untuk pencegahan dan perawatan dispepsia. Hasil ini sejalan dengan penelitian Sumarni dan Andriani (2019) yang mengemukakan bahwa terdapat hubungan antara pola makan dengan kejadian dispepsia di Wilayah Puskesmas Biak, Aceh. Selain itu, sejalan pula dengan hasil penelitian Fithriyana (2018) yang menunjukkan bahwa pola makan adalah salah satu faktor yang berhubungan dengan kejadian dyspepsia di Wilayah Puskesmas Bangkinang Kota.

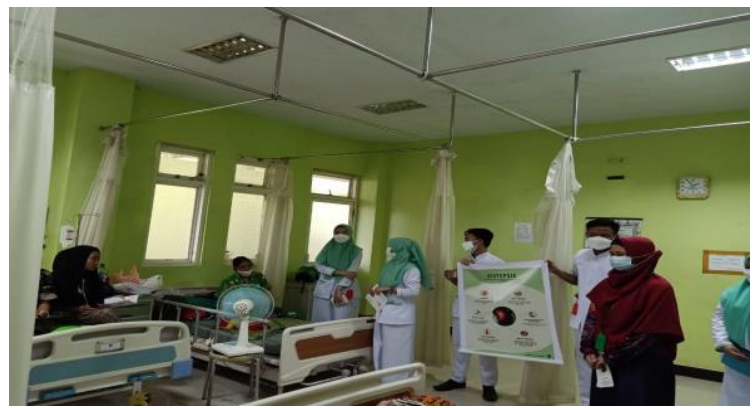

Gambar 1. Penyuluhan Kesehatan

Secara umum, kegiatan penyuluhan kesehatan berlangsung dengan lancar. Peserta dapat mengikuti rangkaian kegiatan hingga akhir. Berdasarkan hasil pre-test dan post-test, terjadi peningkatan pengetahuan. Pasien dan atau keluarga pasien terlihat antusias dan aktif bertanya serta merespon ketika diberikan pertanyaan oleh narasumber. Seluruh peserta yang hadir juga mengikuti kegiatan dari awal hingga akhir kegiatan berlangsung.

\section{Kesimpulan}

Hasil kegiatan pengabdian ini menunjukkan terjadi peningkatan pengetahuan kategori baik sebesar $50 \%$ sebelum dan setelah dilakukan penyuluhan. Disarankan untuk pengabdian berikutnya di komunitas sehingga dapat mendemonstrasikan langsung cara pengolahan obat tradisional untuk dispepsia.

\section{Daftar Pustaka}

Hidayati PS, Iswan Abbas Nusi IA, Maimunah U. Hubungan seropositivitas CagA $H$. pylori 
dengan derajat keparahan gastritis

pada pasien dispepsia. Divisi

Gastroenterohepatologi Departemen

IImu Penyakit Dalam FK UNAIR -

RSU Dr Soetomo Surabaya; 2013.

(Unpublished manuscript).

Fithriyana, R. (2018). Faktor-Faktor Yang

Berhubungan Dengan Kejadian

Dispepsia Pada Pasien Di Willayah

Kerja Puskesmas Bangkinang Kota.

PREPOTIF Jurnal Kesehatan

Masyarakat, 2(2), 2018.

https://journal.universitaspahlawan.ac.i

d/index.php/prepotif/article/view/79

Madisch, A., Andresen, V., Enck, P.,

Labenz, J., Frieling, T., \& Schemann,

M. (2018). The diagnosis and

treatment of functional dyspepsia.

Deutsches Arzteblatt International,

115(13), 222-232.

https://doi.org/10.3238/arztebl.2018.02

22

Miwa H, Ghoshal UC, Gonlachanvit S, et al. Asian consensus report on functional dyspepsia. J Neurogastroenterol Motil. 2012;18:150-68.

Sumarni, S., \& Andriani, D. (2019).

Hubungan Pola Makan Dengan

Kejadian Dispepsia. Jurnal

Keperawatan Dan Fisioterapi (Jkf), 2(1), 61-66.

https://doi.org/10.35451/jkf.v2i1.282

Syam, A. F., Simadibrata, M., Makmun, D., Abdullah, M., Fauzi, A., Renaldi, K., Maulahela, H., \& Utari, A. P. (2017). National Consensus on Management of Dyspepsia and Helicobacter pylori Infection. Acta Medica Indonesiana, 49(3), 279-287. 